\title{
Endocytosis of 1,3- $\beta$-glucans by broad bean cells at the penetration site of the cowpea rust fungus (haploid stage)
}

\author{
Haixin Xu, Kurt Mendgen \\ Lehrstuhl für Phytopathologie, Fakultät für Biologie, Universität Konstanz, Universitätstrasse 10, D-78434 Konstanz, Germany
}

Received: 13 April 1994 / Accepted: 17 June 1994

\begin{abstract}
The penetration hypha of basidiospore-derived infection structures of the cowpea rust fungus (Uromyces vignae Barclay) in epidermal cells of the nonhost, broad bean (Vicia faba L.), was studied with the electron microscope after high-pressure freezing and freeze substitution. After fungal invasion of the epidermis, a plug in the penetration hypha separated the infection structures on the cuticle from the intraepidermal vesicle of the fungus. The plug and the fungal cell wall reacted with a polyclonal $1,3-\beta$-glucan antibody. The plug in the haploid stage seems to have a task similar to the septum formed in the diploid stage of the fungus. Around the penetration hypha, the plant wall stained darkly and a papilla was deposited by the plant. In the papilla, 1,3- $\beta$-glucans were labelled by a monoclonal and a polyclonal antibody. In the infected epidermal cell, clathrin-coated pits, coated vesicles, partially coated reticula and multivesicular bodies were found. The contents of the coated pits, coated vesicles, partially coated reticula and multivesicular bodies bound to monoclonal and polyclonal $1,3-\beta$-glucan antibodies. Accumulation and uptake of this paramural material into the plant cell by endocytosis is concentrated at the fungal penetration site. It may influence the host-parasite interaction.
\end{abstract}

Key words: Basidiospore (infection structure) - Endocytosis - 1,3- $\beta$-Glucan - Uromyces (host penetration) - Vicia (rust infection)

\section{Introduction}

Urediospores and basidiospores of Uromyces spp. differentiate specific infection structures in order to penetrate into the plant leaf. The dikaryotic urediospore locates an

Abbreviations: $\mathrm{CHC}=$ clathrin heavy chain; $\mathrm{CP}=$ coated pit; $\mathrm{CV}=$ coated vesicle; IEV $=$ intraepidermal vesicle; $\mathrm{MVB}=$ multivesicular body; PCR = partially coated reticulum(a)

Correspondence to: K. Mendgen; Fax: 49(7531)883035 appressorium over the stomatal opening and penetrates with a penetration hypha into the substomatal chamber (Mendgen and Deising 1993). The haploid basidiospore produces less-differentiated infection structures. It germinates and produces a small appressorium on the leaf cuticle. An appressorial ring between the appressorium and the plant cuticle seems to seal the penetration area against possible leakage (Metzler 1982). The penetration pore on the bottom of this appressorium is surrounded by a cone of fungal wall material. Probably as an enlongation of the cone, the penetration hypha develops, pierces the plant cuticle, grows into the epidermis and produces the intraepidermal vesicle (Gold and Mendgen 1991). The nonhost interaction between Uromyces vignae, the cowpea rust and Vicia faba, the broad bean was chosen, because $U$. vignae penetrates Vicia faba leaf cuticles with higher efficiency than the host plant, Vigna sinensis (Xu and Mendgen 1991). We have selected this system to study dynamic events at the penetration site. We used high-pressure freezing in combination with freeze substitution and low-temperature embedding techniques in order to "freeze" dynamic events at the penetration site and to apply immunolabelling. We demonstrate endocytosis of 1,3- $\beta$-glucans by the plant cell at the penetration site of the rust fungus.

Fig. 1. A median section of the penetration hypha of Uromyces
vignae at an early stage of infection. The Vicia faba cell wall $(\mathrm{CW})$ is
modified in the penetration zone. Dark material mainly within the
plant cell wall and a papilla $(\mathrm{Pa})$ surround the penetration hypha.
Additional layers (arrowheads) are seen in an ingrowth (star) origi-
nating from the fungal wall $(\mathrm{CW}$, arrow). Many vesicles and partially
coated reticula (arrow) were found in the plant cytoplasm in the
vinicity of the penetration site. $F$, fungus; $M$, mitochodrion.
$\times 28125 ;$ bar $=0.5 \mu \mathrm{m}$

Fig. 2. Microfilaments (arrows) in penetration hypha. $C W$, cell wall. $\times 56250$; bar $=0.5 \mu \mathrm{m}$

Fig. 3. A polyclonal $1,3-\beta$-glucan antibody labelled the ingrowth (star) of the fungal wall $(C W)$ in the penetration hypha $(F)$. $\times 45000 ;$ bar $=0.5 \mu \mathrm{m}$ 


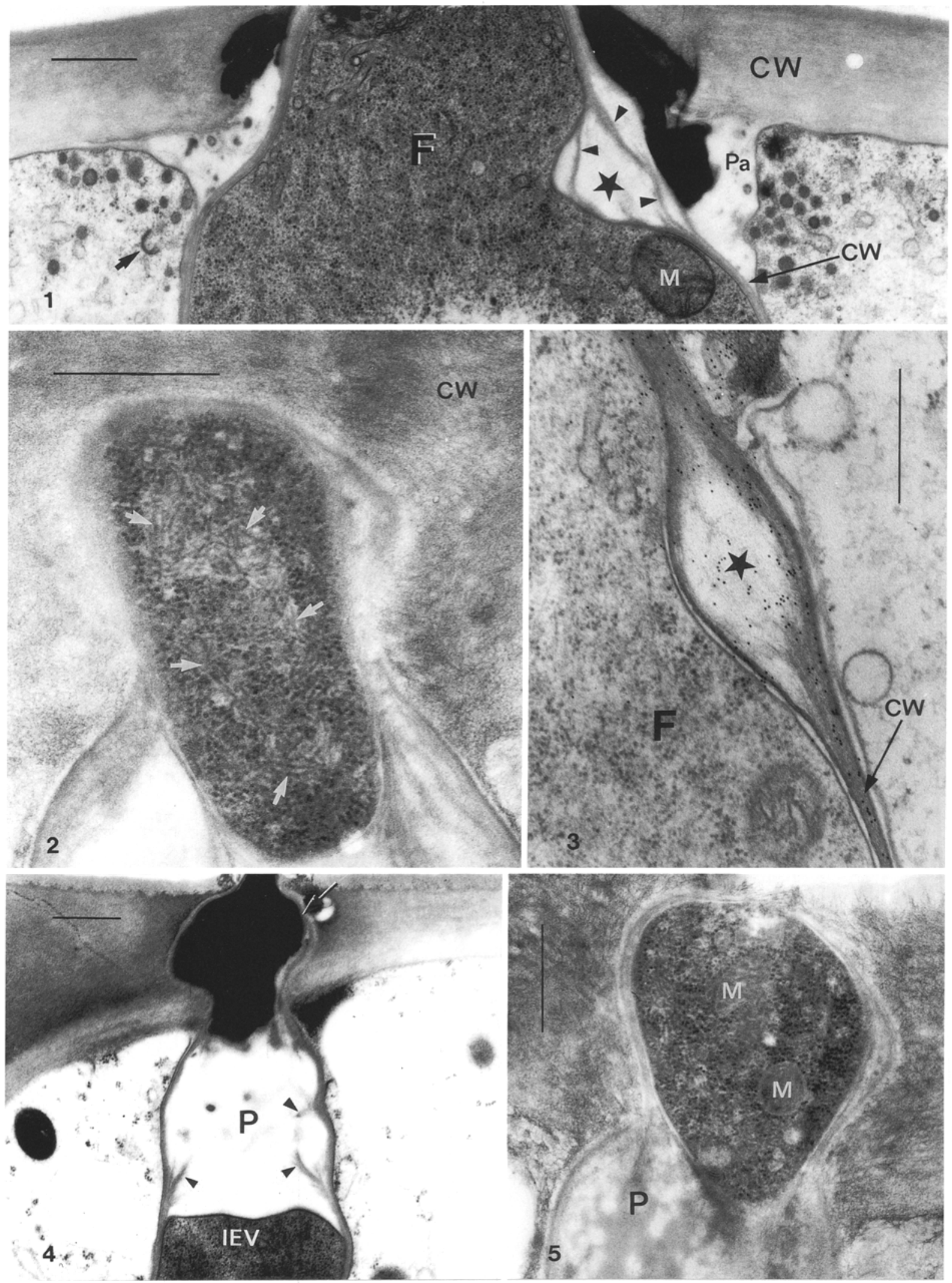

Fig. 4. A median section of penetration hypha at later stage of infection. An electron-transparent plug $(P)$ with the remnant layers (arrowheads) of the fungal wall. Dark material (large arrow) has covered in the proximal part of the penetration hypha. $I E V$, intraepidermal vesicle. $\times 23040$; bar $=0.5 \mu \mathrm{m}$

Fig. 5. Normal cytoplasm in penetration hypha at an earlier stage of infection than that shown in Fig. 4. $M$, mitochodrion; $P$, plug. $\times 36000$, bar $=0.5 \mu \mathrm{m}$ 


\section{Materials and methods}

Plant material and fungal isolate. Broad bean, Vicia faba L. cv. Hedosa (RijksZwaan, The Netherlands) was grown at $20 \pm 2^{\circ} \mathrm{C}$ and illuminated for a 16-h photoperiod with $11000 \mathrm{l}$. Basidiospores of cowpea rust, Uromyces vignae Barclay, race CPR-1 were raised as described by Xu and Mendgen (1991). The expanded primary leaves of 14-d-old broad bean plants were cut off and were inoculated with basidiospores of cowpea rust fungus (Xu and Mendgen 1991).

High-pressure freezing and freeze substitution. Six to eight hours after inoculation, leaf pieces ( $2 \mathrm{~mm}$ diameter) were vacuum-infiltrated with $8 \%$ methanol in water, frozen in a Balzers (Fürstentum Liechtenstein) HPM 010 apparatus (Mendgen et al. 1991) and were stored in liquid nitrogen until freeze substitution. Specimens to be embedded in Epon/Araldite resin mixture were freeze-substituted and embedded as previously described (Knauf et al. 1989).

Specimens to be embedded in LR White resin (The London Resin Co., Basingstoke, Hampshire, UK) were transferred into precooled $\left(-90^{\circ} \mathrm{C}\right) 1.5-\mathrm{ml}$ Eppendorf tubes filled with $0.5 \%(\mathrm{w} / \mathrm{v}) \mathrm{OsO}_{4}$ in acetone as substitution medium. After $2 \mathrm{~d}$ at $-90^{\circ} \mathrm{C}$, the temperature was raised to $-60^{\circ} \mathrm{C},-40^{\circ} \mathrm{C}$ and $-20^{\circ} \mathrm{C}$ for $8 \mathrm{~h}$ each and finally the temperature was maintained at $-20^{\circ} \mathrm{C}$. After several washes of the specimens with acetone, the acetone was replaced by ethanol in several steps $(30 \%, 50 \%, 75 \%, 90 \%$ ethanol in acetone and $3 \times 100 \%$ ethanol for 0.5 to $1 \mathrm{~h}$ each). The specimens were infiltrated with a mixture of $5 \%, 10 \%, 20 \%, 40 \%, 60 \%, 75 \%, 90 \%$, $100 \%$ LR White resin in ethanol for $2 \mathrm{~h}$ each and $3 \times 100 \%$ LR White resin for $12 \mathrm{~h}$ each. Polymerisation was carried out under UV light at $-20^{\circ} \mathrm{C}$ for $24 \mathrm{~h}$, followed at room temperature for $24 \mathrm{~h}$.

Serial ultrathin $(65-75 \mathrm{~nm})$ sections were cut with a diamond knife and collected with copper slot grids (Epon/Araldite resin) for morphological observations and nickel slot grids (LR White) for immunocytochemical studies. The slot grids with the sections floating on a drop of water were settled on a pioloform-coated SPI Domino Rack (SPI Supplies, West Chester, Pa., USA) and allowed to dry (Moran and Rowley 1987).

\section{Antibody probes and labelling procedures.}

Monoclonal 1,3- $\beta$-glucan antibody. Monoclonal antibody to 1,3- $\beta$ glucan has been shown to specifically recognize trimers to octamers of this glucan in cell walls of pollen tubes (Meikle et al. 1991). Sections of rust-infected broad bean leaf on nickel slot grids were blocked with $1 \%(\mathrm{w} / \mathrm{v})$ bovine serum albumin (BSA; Serva, Heidelberg, Germany) in Tris- $\mathrm{HCl}$ buffered saline $(150 \mathrm{mM} \mathrm{NaCl}, 10 \mathrm{mM}$ Tris- $\mathrm{HCl}, \mathrm{pH} 7.4$; TBS) for $15 \mathrm{~min}$ before they were incubated with the monoclonal antibody diluted $1: 20$ in blocking buffer at $4^{\circ} \mathrm{C}$ overnight. After three 5-min washes in TBS mentioned above, the incubation was followed by a 1:10 dilution of rabbit anti-mouse immunoglobulin $\mathrm{G}(\mathrm{IgG})$ conjugated with 10 -nm-diameter colloidal gold particles (Plano Planet, Marburg, Germany) in blocking buffer for $1 \mathrm{~h}$. Subsequently the sections were washed $3 \times 5 \mathrm{~min}$ in TBS and $3 \times 10 \mathrm{~min}$ in distilled water.

Polyclonal 1,3- $\beta$-glucan antibody. Polyclonal antibody to 1,3- $\beta$-glucans (\#CH-11-512; Cambridge Research Biochemicals, Northwich, Cheshire, UK) are characterized specific for 1,3- $\beta$-glucans of cell walls (Northcote et al. 1989). After 30 min blocking in 3\% BSA in TBS as described above, the sections were incubated with the polyclonal antibody diluted $1: 400$ in TBS containing $0.1 \%$ BSA for $1 \mathrm{~h}$, followed by three 10-min washes with $1 \%$ BSA-TBS, and $1 \mathrm{~h}$ incubation with goat anti-rabbit IgG coupled with 10 -nm colloidal gold, diluted $1: 20$ with $0.1 \%$ BSA-TBS before washing three times for $5 \mathrm{~min}$ in TBS, and finally washing with distilled water. Specific antibody binding was checked by preincubating the antibody for $1 \mathrm{~h}$ with $200 \mu \mathrm{g} \mathrm{m}^{-1}$ laminarin (L-9634; Sigma) and with $200 \mu \mathrm{g} \mathrm{ml}^{-1}$ carboxymethylcellulose (C-5678; Sigma) respectively (Hussey et al. 1992).
Polyclonal clathrin heavy chain antibody. Clathrin heavy chain (CHC) antibody was provided by Prof. Dr. D.G. Robinson (Pflanzenphysiologisches Institut, Göttingen, Germany). The polyclonal antibody was prepared against zucchini (Cucurbita pepo $\mathrm{L}$. cv. Cocozelle von Tripolis) hypocotyl CHC. Specific recognition of the $\mathrm{CHC}$ in coated vesicles isolated from diverse higher plants has been demonstrated (Robinson, D.G., personal communication). Sections were blocked in TBS containing 3\% BSA and $0.2 \%$ BSA$\mathrm{C}$ (methylated BSA; Aurion, Wageningen, The Netherlands) for 15 min before incubating with anti-CHC-antibody (diluted 1:500) in TBS containing $1 \%$ BSA for $1 \mathrm{~h}$. After washing in TBS containing $1 \% \mathrm{BSA}$, gold-conjugated goat anti-rabbit $\operatorname{IgG}(10 \mathrm{~nm}$ gold particles) diluted 1:50 in TBS containing 1\% BSA and $0.2 \%$ BSA$\mathrm{C}$ were added and incubated for $1 \mathrm{~h}$, followed by washing in TBS and distilled water.

All labelling procedures were carried out at room temperature except where indicated otherwise. All sections were counter-stained with aqueous uranyl acetate and lead citrate at room temperature before examination in a transmission electron microscope (EM10; Zeiss, Oberkochen, Germany) operated at $60 \mathrm{kV}$.

\section{Results}

Basidiospores of the cowpea rust fungus developed germ tubes, appressoria, penetration hyphae and even intraepidermal vesicles (IEV) within 6-8 h after landing on the cuticle. During processing of the leaf samples, appressoria were torn away and only the penetration hypha and the IEV remained within the leaf. An early stage of penetration hypha development is shown in Fig. 1. The fungal cytoplasm in the penetration hypha was rich in microfilaments (Fig. 2). During migration of the fungal protoplast into the IEV, an ingrowth was observed within the penetration hypha. The ingrowth had a layered structure and these layers appeared to originate from the easily discernible hyphal wall (Figs. 1, 3). The ingrowth had affinity to the polyclonal (Fig. 3), but not to the monoclonal (data not shown) 1,3- $\beta$-glucan antibodies. A later stage of infection structure development is shown in Fig. 4. The protoplast had migrated almost completely into the IEV and the ingrowth of the wall had turned into a plug that separated the penetration pore and the IEV (Fig. 4). The plug remained electron transparent. Like the fungal wall of the IEV shown in Fig. 9, the plug had affinity to the polyclonal 1,3- $\beta$-glucan antibody (Figs. 6 and 7), but not to the monoclonal 1,3- $\beta$-glucan antibody (Fig. 10). No septum pore or a comparable structure was seen in the plug zone. Above the plug, the penetration hypha was often filled with dark material (Fig. 4). This material seemed to consist of degenerated cytoplasm of the fungus since in the earlier infection stages, normal cytoplasm was left behind (Fig. 5)

The plant cell wall in contact with the penetration hypha stained heavily (Figs. 1, 7, 11). A papilla around the penetration hypha of the rust fungus beneath the plant cell wall (Figs. 1,11) consisted of material with heterogeneous staining properties. The papilla had high affinity to both the monoclonal and the polyclonal $1,3-\beta$ glucan antibodies (Figs. 7, 8, 10).

The invaded epidermal protoplasts appeared to remain fully viable $8 \mathrm{~h}$ after inoculation. At the penetration site the plasmalemma was covered with numerous coated 

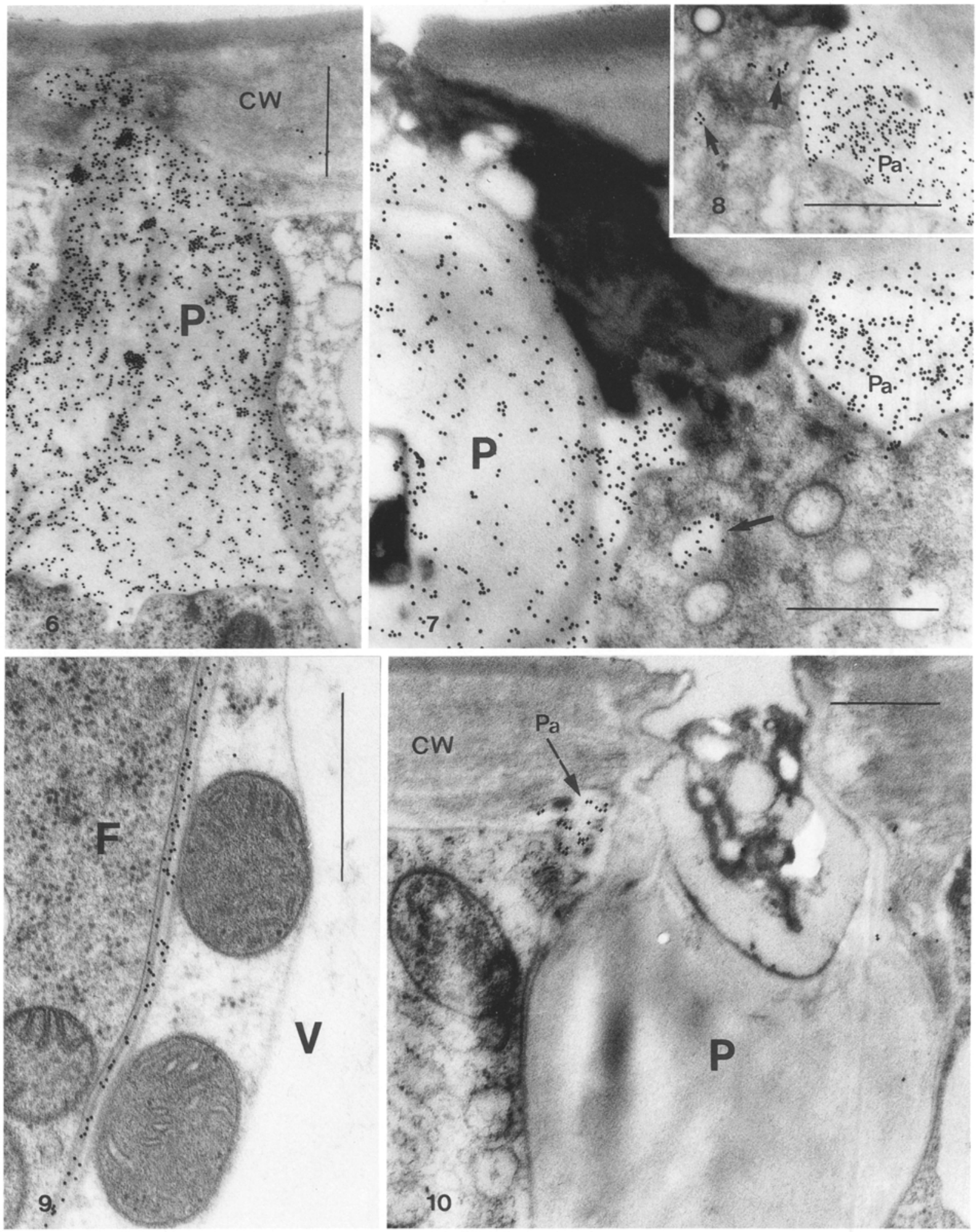

Fig. 6-9. Immunolabelling of the penetration hypha of $U$. vignae with the polyclonal $1,3-\beta$-glucan antibody recognizing branched $1,3-\beta$-glucans. bars $=0.5 \mu \mathrm{m}$. Fig. 6. A near-median section of the penetration site showing the labelling over the plug $(P)$ and the wall of the penetration hypha. $C W$, broad bean cell wall. $\times 36000$. Fig. 7 . Gold labelling over the plug $(P)$ and the papilla $(\mathrm{Pa})$. The arrow indicates a labelled vesicle. $\times 49500$. Fig. 8. Gold labelling over the papilla $(P a)$ and some membrane-bound vesicles (arrows). $\times 45000$.

Fig. 9. Labelled wall of the fungal intraepidermal vesicle $(F)$. $V$, plant vacuole. $\times 63000$

Fig. 10. Monoclonal 1,3- $\beta$-glucan antibodies recognizing linear 1,3$\beta$-glucans bind to the papilla $(P a)$, but not to the plug $(P)$ of the $U$. vignae, indicating a difference in specificity of monoclonal versus polyclonal antibodies. $C W$, broad bean cell wall $\times 36000$, bar $=$ $0.5 \mu \mathrm{m}$ 


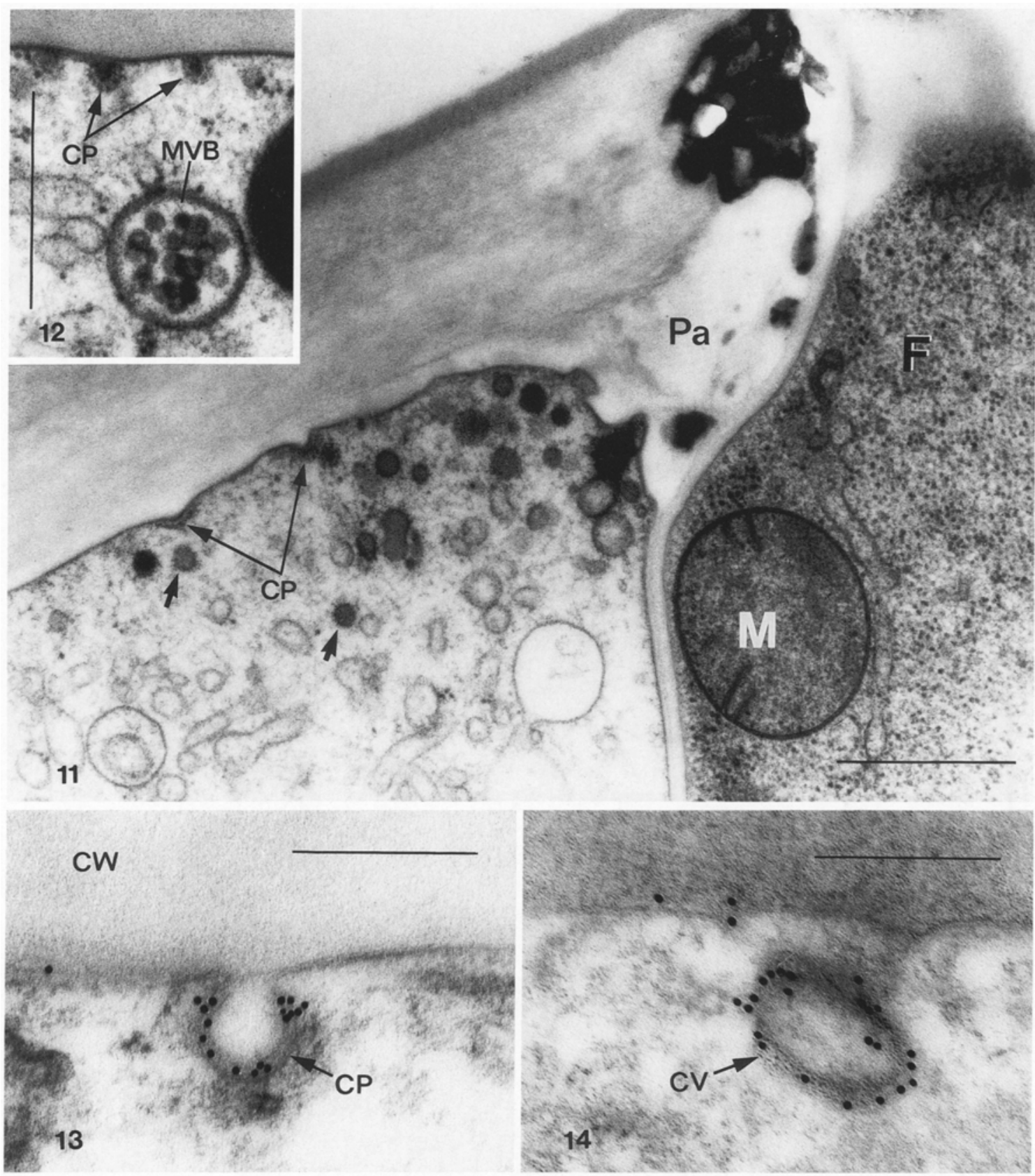

Fig. 11. Coated pits $(C P)$ and coated vesicles (arrows) at the $U$. vignae penetration site of the broad bean plant. $F$, fungus, $P a$, papilla, $M$, mitochodrion. $\times 51750$. bar $=0.5 \mu \mathrm{m}$

Fig. 12. Multivesicular body $(M V B)$ in the vicinity of endocytotic site. $C P$, coated pits. $\times 63000$; bar $=0.5 \mu \mathrm{m}$

Fig. 13-14. Labelling of the coat with a polyclonal $\mathrm{CHC}$ antibody: coated pit $(C P ; 13)$ and coated vesicle $(C V ; 14) . \times 108000$; bars $=0.25 \mu \mathrm{m}$

pits (CP) and the cytoplasm was spotted with many coated and noncoated vesicles (Figs. 1, 11). Partially coated reticula (PCR) and multivesicular bodies (MVB) were also found in the vicinity of the penetration site (Figs. 1, 12). The coats of the CPs and the coated vesicles (CVs) were labelled with CHC antibody (Figs. 13, 14). The contents of CPs, CVs, smooth vesicles, PCR and MVBs reacted

Fig. 15-16. Binding of the monoclonal $1,3-\beta$-glucan antibody to the contents of a coated pit $(C P ; 15 ; \times 139500)$ and a coated vesicle $(C V ; 16 ; \times 99000)$. Arrowhead and arrow indicate the labelling in the coated pit and in a membrane-bound vesicle in the multivesicular body $(M V B)$ respectively (16). $C W$, cell wall. Bars $=0.2 \mu \mathrm{m}$

Fig. 17-21. Labelling of 1,3- $\beta$-glucan with the polyclonal antibody. Fig. 17. Coated pit $(C P)$. $C W$, cell wall. $\times 112500$; bar $=0.2 \mu \mathrm{m}$. Fig. 18. Coated vesicle $(C h)$ and the material in the paramural space. $C W$, cell wall. $\times 112500$; bar $=0.2 \mu \mathrm{m}$. Fig. 19. Multivesicular body $(M V B) . \times 112500 ; \mathrm{bar}=0.2 \mu \mathrm{m}$. Fig. 20. Unusally large multivesicular body and a multivesicular body of normal size (MVB). Arrow indicates the membrane-bound vesicle in the large multivesicular body. $C W$, cell wall; $M$, mitochodrion. $\times 46080$; bar $=0.5 \mu \mathrm{m}$. Fig. 21. Partially coated reticulum $(P C R)$. Arrows indicate the coated region. $\times 50400 ;$ bar $=0.5 \mu \mathrm{m}$ 


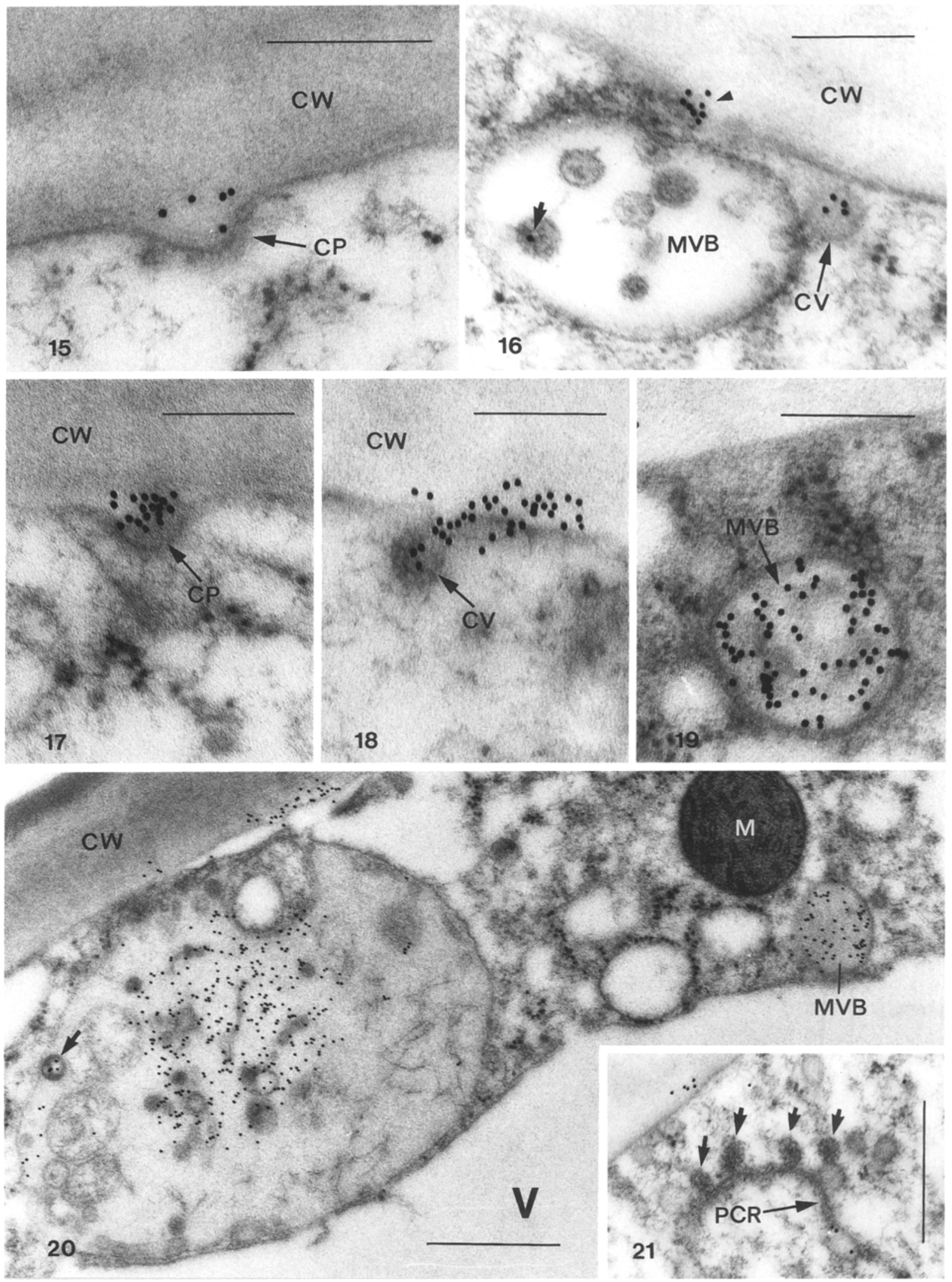


with both the monoclonal (Figs. 15, 16) and the polyclonal (Figs. 7, 8, 17-21) 1,3- $\beta$-glucan antibodies. Some MVBs were unusually large (Fig. 20). Parts of their contents were heavily labelled by the polyclonal 1,3 - $\beta$-glucan antibody (Fig. 20). However, neither the Golgi apparatus nor the vacuole was labelled by either 1,3- $\beta$-glucan antibody (data not shown).

\section{Discussion}

The ultrastructure of host, parasite and their interface are much better preserved by high-pressure freezing and freeze substitution than by conventional chemical fixation. This is due largely to the fact that ultrarapid freezing can stabilize a cell in milliseconds whereas chemical fixation takes minutes (Moor 1987; Mendgen et al. 1991). All molecules become immobilized simultaneously by ultrarapid freezing, whereas selective immobilization of molecules takes place during chemical fixation (Bowers and Maser 1988). These features are of particular importance for the preservation of dynamic organelles such as $\mathrm{CVs}$ and CPs, the latter having a half-life of less than $30 \mathrm{~s}$ (Emos and Traas 1986). Cryofixation can also be used in conjunction with low-temperature acrylic resins recommended for immunocytochemical techniques. Thus considerably more information about the interaction between plant and fungus can be obtained.

After freeze substitution, the wall of the penetration hypha is in intimate contact with, but clearly distinct from, the epidermal wall. The fungal wall is recognized by the polyclonal, but not by the monoclonal $1,3-\beta$-glucan antibody. The latter recognizes linear oligosacharides of this polymer (Meikle et al. 1991). Branched 1,3- $\beta$-glucans are typical constituents of the walls of basidiomycetes (Sietsma and Wessels 1977; Mol and Wessels 1990; Freytag and Mendgen 1991) and of other fungi (Hiura et al. 1984; Horisberger et al. 1985; Latge et al. 1986; Gollotte et al. 1993).

The fungal cytoplasm in the penetration hypha is well preserved and exhibits cytoskeletal elements. In Magnaporthe grisea, actin was detected by immunological techniques in the penetration hypha (Bourett and Howard 1991). These authors suggest that actin reinforces the penetration hypha and thus supports the penetration process.

After differentiation of the IEV of the fungus, the penetration hypha is occluded by a plug. The plug appears to be an extension from the ingrowth of the fungal wall. A similar structure has been observed in penetration hyphae derived from basidiospores of Gymnosporangium fuscum (Metzler 1982) and Uromyces appendiculatus (Gold and Mendgen 1984). Basidiospores of Cronartium fusiforme develop a normal septum in this area (Gray et al. 1982). Therefore, the plug may functionally replace a septum. A septum is also produced in this area of the penetration hypha in the more complex infection structures derived from the dikaryotic urediospores and aecidiospores of rusts (Mendgen and Deising 1993). Metzler (1982) suggested that this plug separates the internal structures of the fungus, the IEV, from the fungal struc- tures formed outside, on the host epidermis and thus inhibits attack by other microorganisms. In addition, we suggest that the plug occludes the penetration hypha and thus helps to build up enough turgor pressure in the IEV to resist the pressure of the plant protoplast. Extremely high turgor pressure has been reported from appressoria of Magnaporthe grisea (Howard et al. 1991) and this was shown to be essential for penetration. The dark material above the plug appears to be a residue of degenerated appressorial cytoplasm.

A papilla is deposited by the plant around the penetration hypha. The papilla reacts with the monoclonal antibody, specific for linear 1,3- $\beta$-glucans and the polyclonal antibody binding to branched 1,3 - $\beta$-glucans. Callose, the main constituent of the papilla, is a mainly linear $1,3-\beta$-glucan which is known to be synthesized at the plasmalemma (Kauss 1994). Inclusions in the papilla indicate that other constituents have been secreted by the plant in addition. Numerous vesicles lacking the typical clathrin coats observed close to the papilla may play a role in papilla formation.

Clathrin-coated pits and coated vesicles in high numbers around the penetration site strongly point to endocytosis by the plant cell. The detection of $1,3-\beta$-glucans in the endocytotic organelles indicates that this material occurs in the space between the cell wall and the plasmalemma, gathers in the area of the CPs and is taken up by the cell. Receptors for $1,3-\beta$-glucans have been described on the membrane of soybean cotyledones (Yoshikama et al. 1983) and on the surface of soybean protoplasts (Schmidt and Ebel 1987; Cheong and Hahn 1991; Ebel and Cosio 1994). Endocytosis of 1,3- $\beta$-glucan, however, has not yet been reported. Uptake of carbohydrates into the plant cell has been demonstrated by electron (Hawes et al. 1989) and light microscopy (O'Driscoll et al. 1993; Horn et al. 1989; Low and Chandra 1994). The occurrence of 1,3- $\beta$-glucans in CVs, smooth vesicles, PCR and MVBs demonstrates endocytosis at the penetration site of the pathogen and supports the suggestion that the pathway of endocytosis is from CVs via uncoated vesicles to PCR and to MVB (Fowke et al. 1991; Galway et al. 1993). The target organelle of endocytosis is the vacuole in plant cells (Hübner et al. 1985; Tanchak and Fowke 1987; Robinson and Hillmer 1990). However, 1,3$\beta$-glucans were not detected in the vacuole in the present study. The $1,3-\beta$-glucans may have been too strongly diluted to be detectable in the vacuole or they may have been degraded by lytic enzymes in the vacuole. The exceptionally large MVBs were only found in infected plant cells. After infection of epidermal cells with Erysiphe graminis, oversized vesicles were observed around the penetration site by light and electron microscopy (Zeyen and Bushnell 1979; Mendgen et al. 1987). Perhaps, formation of large MVBs is an infection specific reaction of plant cells.

The contents of CPs, CVs and MVBs were bound by the monoclonal antibody, specific for linear $1,3-\beta$-glucans. It is possible that these molecules originate from the plant. However, material in such endocytotic organelles was also recognized by the polyclonal $1,3-\beta$-glucan antibody, which binds glucans in the fungal wall. Therefore, 
it is reasonable to suggest that at least a part of the $1,3-\beta-$ glucans in these organelles might either have a structure similar to the fungal wall material or may even have originated from the fungal wall. Fungal $1,3-\beta$-glucans have been described as active elicitors in phytoalexin synthesis (Yoshikawa et al. 1983; Cosio et al. 1988; Aldington and Fry 1993).

Modifications of the plant cell wall in contact with the penetration hypha were also observed after infection with smut fungus (Snetselaar and Mims 1993), rust fungus (Mims et al. 1989), powdery mildew (McKeen et al. 1969; Hippe-Sanwald et al. 1992) and Colletotrichum lindemuthianum (O'Connell and Bailey 1986). Different staining features of cell walls suggest chemical modifications. Possibly the cell wall around the penetration hypha is enzymatically degraded by the fungus during the penetration process (Mendgen and Deising 1993). Many degradation products of the plant cell wall are active elicitors of phytoalexins or phytotoxins. Galacturonides, xyloglucans, hemicellulose, probably xylan, $\mathrm{N}$-linked glycoprotein (Hahne and Lörz 1988; Aldington and Fry 1993 ) and even 1,4- $\beta$-glucans (Lorences et al. 1990) are reported to have elicitor activity or to be phytotoxic. However, we were not able to detect such materials in the endocytotic organelles e.g. CPs, CVs and MVBs with available antibodies (data not shown). Small amounts of these molecules may have been washed out during processing of our samples or the concentration may have been below the limit of detection.

This study shows that the broad bean plant not only secretes material in an attempt to block fungal ingress, but also takes up material(s) such as 1,3- $\beta$-glucans from the outside of the plasmalemma. Thus, a message from the events outside, consisting of degradation products of plant or fungal cell walls may be taken up by the plant at the site of penetration and this signal may influence the outcome of infection. In the combination of nonhost interaction studied here, hypersensitive plant cell death starts about $6 \mathrm{~h}$ after fungal penetration (Xu and Mendgen 1991) and after the observation of endocytosis.

We are grateful to Dr. D.G. Robinson (Pflanzenphysiologisches Institut, Universität Göttingen, Germany) for the clathrin antibody and to Drs. D.G. Robinson (Pflanzenphysiologisches Institut, Universität Göttingen, Germany), R. O'Connell (University of Bristol, UK), H. Deising and M. Hahn (Konstanz) for critically reading this manuscript and discussion. The first author thanks the FriedrichNaumann-Stiftung for a fellowship.

\section{References}

Aldington, S., Fry S.C. (1993) Oligosaccharins. Adv. in Bot. Res. 19, $1-101$

Bourett, T.M., Howard, R.J. (1991) Ultrastructural immunolocalization of actin in a fungus. Protoplasma 163, 199-202

Bowers, B., Maser, M. (1988) Artifacts in fixation for transmission electron microscopy. In: Artifacts in biological electron microscopy, pp. 13-42, Crang, R.F.E., Klomparens K.L. eds. Plenum Press, New York London

Cheong, J.-J., Hahn, M.G. (1991) A specific, high-affinity binding site for the hepta- $\beta$-glucoside elicitor exists in soybean membrane. Plant Cell 3, 137-147
Cosio, E.G., Pöpperl, H., Schmidt, W.E., Ebel, J. (1988) High affinity binding of fungal $\beta$-glucan fragments to soybean (Glycine max L.) microsomal fractions and protoplasts. Eur. J. Biochem. 175, 309-315

Ebel, J., Cosio, E.G. (1994) Elicitors of plant defence responses. Int. Rev. Cytol. 148, 1-36

Emons, A.M., Traas, J.A. (1986) Coated pits and coated vesicles on the plasma membrane of plant cells. Eur. J. Cell Biol. 41, 57-64

Fowke, L.C., Tanchak, M.A., Galway, M.E. (1991) Ultrastructural cytology of the endocytotic pathway in plants. In: Endocytosis, exocytosis and vesicle traffic in plants, pp. 15-40, Hawes, C.R., Coleman, J.O.D. Evans, D.E., eds. Cambridge University Press, Cambridge

Freytag, S., Mendgen, K. (1991) Surface carbohydrates and cell wall structure of in vitro-induced uredospore infection structure of Uromyces viciae-fabae before and after treatment with enzymes and alkali. Protoplasma 161, 94-103

Galway, M.E., Rennie, P.J., Fowke, L.C. (1993) Ultrastructure of the endocytotic pathway in glutaraldehyde-fixed and high-pressure frozen/freeze-substituted protoplasts of white spruce (Picea glauca). J. Cell Sci. 106, 847-859

Gold, R.E., Mendgen, K. (1984) Cytology of basidiospore germination, penetration, and early colonization of Phaseolus vulgaris by Uromyces appendiculatus var. appendiculatus. Can. J. Bot. 65, 1989-2002

Gold, R.E., Mendgen, K. (1991) Rust basidiospore germlings and disease initiation. In: The fungal spore and disease initiation in plants and animals, pp. 67-99, Cole, G.T., Hoch, H.C., eds. Plenum Press, New York

Gollotte, A., Gianinazzi-Pearson. V., Giovannetti, M., Sbrana, C., Avio, L., Gianinazzi, S. (1993) Cellular localization and cytochemical probing of resistance reactions of arbuscular mycorrhizal fungi in a 'locus a' myc' mutant of Pisum sativum L. Planta $191,112-122$

Gray, D.J., Amerson, H.V., Van Dyke, C.G. (1982) An ultrastructural comparison of monokaryotic and dikaryotic haustoria formed by the fusiform rust fungus Cronartium quercuum $\mathrm{f}$. sp. fusiforme. Can. J. Bot. 60, 2914-2922

Hahne, G., Lörz, H. (1988) Release of phytotoxic factors from plant cell walls during protoplast isolation. J. Plant Physiol. 132, 345350

Hawes, C., Coleman, J., Evans D., Cole, L. (1989) Recent advances in the study of plant coated vesicles. Cell Biol. Int. Rep. 13, $119-128$

Hippe-Sanwald, S., Hermanns, M., Somerville, S.C. (1992) Ultrastructrural comparison of incompatible and compatible interactions in the barley powdery mildew disease. Protoplasma 168, $27-40$

Hiura, N., Honjyo, I., Nakajima, T., Matsuda, K. (1984) Change of the structure of cell wall $\beta-1,3-D-g l u c a n$ with the growth of Neurospora crassa cells. Agric. Biol. Chem. 48, 1041-1047

Horisberger, M., Rouvet-Vauthey, M., Richli, U., Farr, D.A. (1985) Cell wall architecture of the halophilic yeast Saccharomyces rouxii. An immunocytochemical study. Eur. J. Cell Biol. 37, $70-77$

Horn, M.A., Heinstein, P.F., Low, P.S. (1989) Receptor-mediated endocytosis in plant cells. Plant Cell 1, 1003-1009

Howard, R.J., Ferrari, M.A., Roach, D.H., Money, N.P. (1991) Penetration of hard substrates by a fungus employing enormous turgor pressures. Proc. Nati. Acad. Sci. USA 88, 11281-11284

Hübner, R., Depta, H., Robinson, D.G. (1985) Endocytosis in maize root cap cell. Evidence obtained using heavy metal salt solutions. Protoplasma 129, 214-222

Hussey, R.S., Mims, C.W., Westcott, S.W. (1992). Immunocytochemical localization of callose in root cortical cells parasitized by the ring nematode Criconemella xenoplax. Protoplasma 171, 1-6

Kauss, H. (1994) Callose synthesis. In: Membranes: Specialized functions in plant cells. Smallwood, M. Knox, P., Bowles, D.J., eds. JAI Press. 45, 609-631 
Knauf, G.M., Welter, K., Müller, M., Mendgen, K. (1989) The haustorial host-parasite interface in rust-infected bean leaves after high-pressure freezing. Physiol. Mol. Plant Pathol. 34, 519-530

Latge, J.P., Cole, G.T., Horisberger, M., Porevost, M.G. (1986) U1trastructure and chemical composition of the ballistospore wall of Conidiobolus obscurus. Exp. Mycol. 10, 99-113

Lorences, E.P., McDougall, G.J., Fry, S.C., (1990) Xyloglucan- and cello-oligosaccharides antagonists of the growth-promoting effect of $\mathrm{H}^{+}$. Physiol. Plant. 80, 109-113

Low, P.S., Chandra, S. (1994) Endocytosis in plants. Annu. Rev. Plant Physiol. Plant Mol. Biol. 45, 609-631

Mckeen, W.E., Smith, R., Bhattacharya, P.K. (1969) Alterations of the host wall surrounding the infection peg of powdery mildew fungi. Can. J. Bot. 47, 701-706

Meikle, P.J., Boning, I., Hoogenraad, N.J., Clarke, A.E., Stone, B.A. (1991) The location of $(1 \rightarrow 3)$-B-glucans in the walls of pollen tubes of Nicotiana alata using a $(1 \rightarrow 3)-\beta$-glucan specific monoclonal antibody. Planta 185, 1-8

Mendgen, K., Deising, H. (1993) Infection structures of fungal plant pathogens - a cytological and physiological evaluation. Tansley Review No. 48. New Phytol. 124, 193-213

Mendgen, K., Keller, G., Kuhn, Ch., Inst. Wiss. Film (1987) Infektion und Wirtsreaktion beim Gerstenmehitau. Film C 1642 des IWF, Göttingen. Publikation von K. Mendgen, Publ. Wiss. Film., Sekt. Biol,, Ser. 19, Nr. 19/C 1642 (1987), 19 S

Mendgen, K., Welter, K. Scheffold, F., Knauf-Beiter, G. (1991) Highpressure freezing of rust infected plant leaves. In: Electron microscopy of plant pathogens, pp. 31-42, Mendgen, K., Lesemann, D.-E., eds. Springer, Berlin

Metzler, B. (1982) Untersuchungen an Heterobasidiomyceten (23): Basidiosporenkeimung und Infektionsvorgang beim Birnengitterrost. Phytopath. Z. 103, 126-138

Mims, C.W., Taylor, J. Richardson, E.A. (1989) Ultrastructure of the early stages of infection of peanut leaves by the rust fungus Puccinia arachidis. Can. J. Bot. 67, 3570-3579

Mol, P.C., Wessels, J.G.H. (1990) Differences in wall structure between substrate hyphae and hyphae of fruit-body stipes in Agaricus bisporus. Mycol Res. 94, 472-479

Moor, H (1987) Theory and practice of high-pressure freezing. In: Cryotechniques in biological electron microscopy, pp. 175-191. Steinbrecht, R.A., Zierold, K., eds. Springer, Berlin Heidelberg
Moran, D.T., Rowley, J.C. (1987) Biological specimen preparation for correlative light and electron microscopy. In: Correlative microscopy: Instrumentation and methods, pp. 1-22, Hayat, M.A., ed. Academic Press, New York

Northcote, D.H., Davey R., Lay, J. (1989) Use of antisera to localize callose, xylan and arabinogalactan in the cell-plate, primary and secondary walls of plant cells. Planta 178, 353-366

O'Connell, R., Bailey, J.A. (1986) Cellular interactions between Phaseolus vulgaris and the hemibiotrophic fungus Colletotrichum lindemuthianum. In: Biology and molecular biology of plant-pathogen interactions, NATO ASI Series, Vol. H1, pp. 39-48. Bailey, J., ed. Springer-Verlag, Berlin Heidelberg

O’Driscoll, D., Hann, C., Read, S.M., Steer, M.W. (1993) Endocytotic uptake of fluorescent dextrans by pollen tubes grown in vitro. Protoplasma 175, 126-130

Robinson, D.G., Hillmer, S. (1990) Endocytosis in plants. Physiol. Plant. 79, 96-104

Schmidt, W.E., Ebel, J. (1987) Specific binding of a fungal glucan phytoalexin elicitor to membrane fractions from soybean Glycine max. Proc. Natl. Acad. Sci. USA 84, 4117-4121

Sietsma, J.H., Wessels, J.G.H. (1977) Chemical analysis of the hyphal wall of Schizophyllum commune. Biochim. Biophys. Acta 496, 225-239

Snetselaar, K.M., Mims, C.W (1993) Infection of maize stigmas by Ustilago maydis: Light and electron microscopy. Phytopathology 83, 843-850

Tanchak, M.A., Fowke, L.C. (1987) The morphology of multivesicular bodies in soybean protoplasts and their role in endocytosis. Protoplasma 138, 173-182

$\mathrm{Xu}, \mathrm{H}$., Mendgen, K. (1991) Early events in living epidermal cells of cowpea and broad bean during infection with basidiospores of the cowpea rust fungus. Can. J. Bot. 69, 2279-2285

Yoshikawa, M., Keen, N.T., Wang, M.C. (1983) A receptor on soybean membranes for a fungal elicitor of phytoalexin accumulation. Plant Physiol. 73, 497-506

Zeyen, R., Bushnell, W.R. (1979) Papilla response of barley epidermal cells caused by Erysiphe graminis: rate and method of deposition determined by microcinematography and transmission electron microscopy. Can. J. Bot. 57, 898-913 